\title{
CD44-related Chondroitin Sulfate Proteoglycan, a Cell Surface Receptor Implicated with Tumor Cell Invasion, Mediates Endothelial Cell Migration on Fibrinogen and Invasion into a Fibrin Matrix
}

\author{
Craig A. Henke, ${ }^{\star}$ Urvashi Roongta, ${ }^{\star}$ Daniel J. Mickelson, ${ }^{\ddagger}$ Jennifer R. Knutson, ${ }^{\ddagger}$ and James B. McCarthy ${ }^{\ddagger}$ \\ Departments of $*$ Medicine and ${ }^{\ddagger}$ Laboratory Medicine and Pathology, University of Minnesota, Minneapolis, Minnesota 55455
}

\begin{abstract}
Microvascular endothelial cell invasion into the fibrin provisional matrix is an integral component of angiogenesis during wound repair. Cell surface receptors which interact with extracellular matrix proteins participate in cell migration and invasion. Malignant cells use CD44-related chondroitin sulfate proteoglycan (CSPG) as a matrix receptor to mediate migration and invasion. In this study, we examine whether cell surface CSPG can mediate similar events in nonmalignant wound microvascular endothelial cells or whether use of CSPG for migration and invasion is a property largely restricted to malignant cells. After inhibiting CSPG synthesis with $p$-nitrophenyl $\beta$-d xylopyranoside ( $\beta$-d xyloside), wound microvascular endothelial cells were capable of attaching and spreading on the surface of a fibrin gel; however, their ability to invade the fibrin matrix was virtually eliminated. To begin to examine the mechanism by which endothelial cells use CSPG to invade fibrin matrices, cell adhesion and migration on fibrinogen was examined. Endothelial cell adhesion and migration on fibrinogen were inhibited by both $\beta$-d xyloside and after cleavage of chondroitin sulfate from the core protein by chondroitinase $\mathrm{ABC}$. We have determined that wound microvascular endothelial cells express the majority of their proteoglycan as CSPG and that the CSPG core protein is immunologically related to CD44. PCR studies show that these cells express both the "standard" (CD44H) isoform and an isoform containing the variably spliced exon V3. In addition, anti-CD44 antibody blocks endothelial cell migration on fibrinogen. Affinity chromatography studies reveal that partially purified microvascular endothelial cell CSPG binds fibrinogen. These findings suggest that CD44-related CSPG, a molecule implicated in the invasive behavior of tumor cells, is capable of binding fibrinogen/fibrin, thereby mediating endothelial cell migration and invasion into the fibrin provisional matrix during wound repair. (J. Clin. Invest. 1996. 97:25412552.) Key words: wound healing • angiogenesis • cell movement $•$ cell surface receptor $\cdot \mathrm{CD} 44-$ related chondroitin sulfate proteoglycan
\end{abstract}

Address correspondence to Craig A. Henke, M.D., Pulmonary and Critical Care Division, Department of Medicine, UMHC Box 276, University of Minnesota, 420 Delaware St. S.E., Minneapolis, MN 55455. Phone: 612-624-0999; FAX: 612-625-2174.

Received for publication 25 October 1994 and accepted in revised form 14 March 1996.

J. Clin. Invest.

(C) The American Society for Clinical Investigation, Inc.

0021-9738/96/06/2541/12 \$2.00

Volume 97, Number 11, June 1996, 2541-2552

\section{Introduction}

After tissue injury, plasma fibrinogen extravasates from blood vessels into the extravascular space where it becomes clotted to cross-linked fibrin forming a provisional matrix in the wound (1). In response to migration promoting signals present within the provisional matrix $(2,3)$, microvascular endothelial cells invade into the fibrin matrix and form an extensive capillary network, providing an integral component of granulation tissue during wound healing $(4,5)$. The initiation of endothelial cell invasion involves a series of interdependent events, including detachment from the physiological matrix, migration, and attachment to the provisional matrix comprised of fibrin and other plasma-derived components.

Endothelial cells adhere and migrate on fibrin and its precursor fibrinogen via cell surface receptors that interact with distinct domains on extracellular matrix $(\mathrm{ECM})^{1}$ proteins. One well characterized mechanism of cell adhesion to ECM proteins involves integrins. Endothelial cells express $\alpha_{v} \beta_{3}$ integrin which binds fibrinogen via an RGD dependent mechanism (69). Despite the recognized importance of integrins in mediating cell adhesion, there are additional cell surface molecule(s) that play an important role in mediating endothelial cell migration and invasion. For example, there is increasing evidence that endothelial cell migration can be associated with the expression of distinct cell surface matrix receptors that mediate migration (10). Additionally, wounded large vessel endothelial cells in culture rapidly change proteoglycan synthesis from heparan sulfate to chondroitin sulfate as migration is initiated, linking chondroitin sulfate expression with the process of cell motility (11).

Studies evaluating tumor cell motility link cell surface chondroitin sulfate proteoglycan (CSPG) with migration and invasion. Malignant cells synthesize increased levels of CSPG which can be found on microspikes on the cell surface (12). Microspikes are a specific cell surface microdomain believed to facilitate the initial contact of the cell with the ECM. Melanoma cell surface CSPG, which contains a core protein recognized by $\mathrm{CD} 44$ antibodies, plays an important role in mediating melanoma cell motility and invasion into type I collagen gels (13). Although the mechanism by which cell surface CD44-related CSPG mediates tumor cell migration and invasion remains to be elucidated, CD44 has been implicated in mediating cell-cell and cell-ECM interactions and is associated with the cell cytoskeleton $(14,15)$ and plays a role in cell migration (16). CD44 is a transmembrane glycoprotein with extracellular, membrane, and cytoplasmic domains (17). The

1. Abbreviations used in this paper: $\alpha$-D xyloside; $p$-nitrophenyl $\alpha$-D xylopyranoside; $\beta$-D xyloside, $p$-nitrophenyl $\beta$-D xylopyranoside; CSPG, chondroitin sulfate proteoglycan; ECM, extracellular matrix; GAG, glycosaminoglycan. 
extracellular domain of CD44 is capable of binding a variety of ECM molecules (18) and contains attachment sites for chondroitin sulfate (19-21). Studies using tumor cells link CD44 with cell motility (22). Importantly, the expression of specific splice variants of CD44 $(23,24)$ and the overexpression of CD44 cDNA clones in tumor cells (25) have been associated with tumor growth and metastasis.

The present study intends to further examine the role of cell surface CSPG in mediating microvascular endothelial cell adhesion, migration, and invasion into the fibrin provisional matrix. To determine whether CSPG influences endothelial cell adhesion, migration, and invasion on fibrinogen/fibrin, we examined the effect of $\beta$-D xylopyranoside ( $\beta$-D xyloside), an agent that competitively inhibits the coupling of chondroitin sulfate to the core protein (26), and chondroitinase ABC, an agent that cleaves the chondroitin sulfate from the core protein, using standard adhesion, migration, and invasion assays. Our results show that $\beta$-D xyloside inhibits the invasion of microvascular endothelial cells into three-dimensional fibrin gels. Furthermore, haptotactic migration and adhesion of endothelial cells on fibrinogen was inhibited by both $\beta$-D xyloside and chondroitinase $\mathrm{ABC}$. We have determined that wound microvascular endothelial cells express the majority of their proteoglycan as CSPG and that the CSPG core protein is immunologically related to CD44. PCR studies reveal that wound microvascular endothelial cells express both the "standard" $(\mathrm{CD} 44 \mathrm{H})$ isoform and an isoform containing the variably spliced exon V3. Thus, CD44-related CSPG, a molecule implicated in the invasive behavior of tumor cells, may play a role in mediating endothelial cell migration and invasion into the fibrin provisional matrix during wound healing.

\section{Methods}

Cell culture and endothelial cell characterization. Wound microvascular endothelial cells were isolated from sponges implanted into the backs of rabbits, as previously described (2). The cells were identified as endothelial cells by positive staining for vWf, angiotensin-converting enzyme, and Factor VIII-related antigen, and by selective uptake of acetylated LDL. The microvascular endothelial cells were cultured in M199 (Gibco Laboratories, Grand Island, NY) supplemented with $20 \%$ heat-inactivated FCS (Sigma Chemical Co., St. Louis, MO), and subcultivated weekly at a split ratio of 1:2. Wound microvascular endothelial cells were used for subsequent experiments at $50-75 \%$ of their saturation density unless otherwise specified, and before the 10th subcultivation.

Cell adhesion and migration assays. Cell adhesion to protein coated substrata was performed as previously described $(2,27)$ using $0.005-5 \mu \mathrm{M}$ fibrinogen. Endothelial cell cultures were radiolabeled $(18 \mathrm{~h})$ with $\left[{ }^{3} \mathrm{H}\right]$ thymidine $(2 \mu \mathrm{Ci} / \mathrm{ml})$, released with enzyme solution ( $0.5 \%$ collagenase, $0.2 \%$ DNase I in PBS, $\mathrm{pH} 7.4$ ), washed, and resuspended to a final concentration of $5 \times 10^{4} \mathrm{cells} / \mathrm{ml}$ in adhesion medium (DME [Sigma Chemical Co.] supplemented with $20 \mathrm{mM}$ Hepes, $5 \mathrm{mg} / \mathrm{ml}$ BSA [fatty acid free; Sigma Chemical Co.]). $5 \times 10^{3}$ cells/well were added in $100 \mu \mathrm{l}$ adhesion medium and allowed to adhere to protein-coated substrata $(1 \mathrm{~h})$. After gentle washing $(4 \times)$ adherent cells were solubilized in $150 \mu \mathrm{l}$ of $0.5 \mathrm{~N} \mathrm{NaOH}$ containing $1 \%$ SDS, and radioactivity was quantitated with a liquid scintillation counter (Beckman LS 7500; Beckman Instruments, Inc., Fullerton, CA).

Endothelial cell migration was assayed in 48-well modified Boyden chambers (Neuroprobe, Bethesda, MD) as described previously (2). The undersides of $8-\mu \mathrm{m}$ pore size polyvinyl pyrrolidone-free polycarbonate filters (Nucleopore Corp., Pleasanton, CA) were precoated with fibrinogen $(0.1-5 \mu \mathrm{M})$. The lower wells of the modified
Boyden chambers were filled with DME, $20 \mathrm{mM}$ Hepes, and $5 \mathrm{mg} / \mathrm{ml}$ BSA. Microvascular endothelial cells were released with enzyme solution ( $0.5 \%$ collagenase, $0.2 \%$ DNase I in PBS, $\mathrm{pH} 7.4)$, washed, and resuspended to a final concentration of $1 \times 10^{6}$ cells $/ \mathrm{ml}$ in DME, 20 $\mathrm{mM}$ Hepes, and $5 \mathrm{mg} / \mathrm{ml} \mathrm{BSA}$. Cells were added to the upper wells at $4.5 \times 10^{4}$ cells/well and migration to the underside of the precoated filter was measured after $4 \mathrm{~h}$ at $37^{\circ} \mathrm{C}$.

Invasion gels. Gels composed of fibrin were prepared under sterile conditions using a modification of the protocol described by Dvorak et al. (4). Human thrombin $(0.2 \mathrm{U} / \mathrm{ml}$; Sigma Chemical Co.) was added to HPLC-DEAE purified rabbit fibrinogen $(3 \mathrm{mg} / \mathrm{ml}$; Sigma Chemical Co.) dissolved in DME containing $20 \mathrm{mM}$ Hepes,

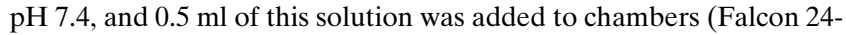
well plates; Becton Dickinson Labware, Lincoln Park, N.J.) before polymerization. The solution was gently swirled to allow uniform distribution and allowed to solidify $\left(30 \mathrm{~min}, 37^{\circ} \mathrm{C}\right)$. Cultures of wound microvascular endothelial cells were harvested with enzyme solution ( $0.5 \%$ collagenase, $0.2 \%$ DNase I in PBS, $\mathrm{pH} 7.4)$, washed, and resuspended in DME containing $2.5 \%$ heat-inactivated calf serum. A cell suspension containing $5 \times 10^{4}$ cells was added to the top of the fibrin gels and the plates were gently swirled to obtain an even distribution of the cells on the gel surface. The gels were incubated $\left(37^{\circ} \mathrm{C}, 5 \%\right.$ $\mathrm{CO}_{2}$ ) in a humidified incubator with media replenished three times per wk.

Cell invasion was measured by quantifying the number of tubular networks formed by invading microvascular endothelial cells using an inverted phase contrast microscope (IMT-2; Olympus Corp., Lake Success, NY). By focusing into the gel, invading cells forming tubular networks could be clearly identified by their position below the original starting plane containing the monolayer of cells on the top surface of the gel. Quantification of the number of tubular networks formed by invading microvascular endothelial cells was performed on days 4 , 7,10 , and 14. Data are presented as the total number of tubular networks formed by invading cells per gel. Results are reported as the means \pm SEM of quadruplicate gels.

$\beta$-D xyloside and chondroitinase ABC pretreatment. For adhesion, migration, and invasion assays, cells were treated with $\beta$-D xyloside ( $p$-nitrophenyl- $\beta$-D-xylopyranoside; Sigma Chemical Co.) for $48 \mathrm{~h}$ to inhibit CSPG synthesis by replacing the medium of cell cultures with DME containing $2.5 \%$ heat-inactivated calf serum, with or without $\beta$-D xyloside. $\alpha$-D xyloside ( $p$-nitrophenyl- $\alpha$-D-xylopyranoside; KochLight Ltd., Suffolk, England) does not inhibit CSPG synthesis and was used as a control. $\alpha$ - or $\beta$-D xyloside was also included in the medium during the assays. For invasion assays, cells were seeded onto the gels as described above in the presence of varying concentrations of $\alpha$ - or $\beta$-D xyloside. Additionally, fibrin gels used in the $\alpha$ - and $\beta$-D xyloside experiments were composed of fibrinogen dissolved in DME, $20 \mathrm{mM}$ Hepes, containing varying concentrations of either $\alpha$ or $\beta$-D xyloside.

For chondroitinase $\mathrm{ABC}$ treatment, cells were pretreated with varying concentrations of chondroitinase $\mathrm{ABC}\left(15 \mathrm{~min}, 37^{\circ} \mathrm{C}\right.$; Sigma Chemical Co.) before adhesion and migration assays as previously described (13). Chondroitinase ABC was also included in the cell medium during the adhesion and migration assays.

Inhibition assay: anti-CD44 $m A b$. An inhibition bioassay using a mouse anti-human CD44 mAb (BU52; The Binding Site, Inc., San Diego, CA) was performed to assess the role of CD44 in mediating microvascular endothelial migration on fibrinogen. Briefly, for the migration assay, microvascular endothelial cells were preincubated $\left(30 \mathrm{~min}, 37^{\circ} \mathrm{C}\right)$ with the anti-CD44 $\mathrm{mAb}(0.02-20 \mu \mathrm{g} / \mathrm{ml})$ and added to the upper wells of the modified Boyden chambers. Migration to the underside of the precoated filter was measured after $4 \mathrm{~h}$ at $37^{\circ} \mathrm{C}$. Control assays were performed substituting normal mouse IgG antibody for the anti-CD44 mAb.

Extraction and purification of microvascular endothelial cell proteoglycans. Microvascular endothelial cell proteoglycans were preferentially labeled with $\left[{ }^{35} \mathrm{~S}\right]$ sulfate $\left(18 \mathrm{~h}, 37^{\circ} \mathrm{C}\right)$ by replacing the medium in cultures with low sulfate DME $\left(0.1 \mathrm{mM} \mathrm{Na}_{2} \mathrm{SO}_{4}\right.$, Gibco Laborato- 
ries) containing $50 \mu \mathrm{Ci} / \mathrm{ml} \mathrm{Na}_{2}{ }^{35} \mathrm{SO}_{4}$ (Carrier free, sp act $43 \mathrm{Ci} / \mathrm{mg}$; ICN Biomedicals, Irvine, CA). Proteoglycans were extracted by adding $30 \mathrm{ml}$ cellular extraction buffer $(0.15 \mathrm{M} \mathrm{NaCl}, 10 \mathrm{mM}$ Tris, $5 \mathrm{mM}$ $\mathrm{MgCl}_{2}, 2 \mathrm{mM}$ EDTA, $0.25 \mathrm{mM}$ DTT, $1 \mathrm{mM}$ PMSF, $1 \%$ Triton X-100, $\mathrm{pH}$ 7.2) to each culture flask $\left(75 \mathrm{~cm}^{2}\right.$; Corning Glass Works, Corning, $\mathrm{NY})$ and incubated $\left(20 \mathrm{~min}, 37^{\circ} \mathrm{C}\right)$. The cellular extracts were centrifuged (1,500 rpm, $5 \mathrm{~min})$ to remove insoluble material. The extracts were dialyzed (mol wt cut off 3,500 ) against successive changes of acetate buffer $\left(0.5 \mathrm{M} \mathrm{C}_{2} \mathrm{H}_{3} \mathrm{O}_{2} \mathrm{Na}\right.$, pH 6.8, $0.1 \mathrm{Na}_{2} \mathrm{SO}_{4}, 10 \mathrm{mM}$ EDTA, $0.1 \mathrm{mM}$ PMSF, $10 \mathrm{mM}$ 6-aminohexanoic acid) until the amount of radioactivity in the dialysate buffer was at background levels (13).

Anion exchange chromatography of detergent-extracted CSPG. Detergent-extracted ${ }^{35} \mathrm{~S}$-proteoglycans were dialyzed into DEAE buffer (0.15 M Tris, $6.0 \mathrm{M}$ urea, $0.1 \mathrm{M} \mathrm{NaCl}, 0.01 \mathrm{M}$ EDTA, $0.01 \mathrm{M}$ 6-aminohexanoic acid, $0.2 \%$ Triton X-100, $0.1 \mathrm{mM}$ PMSF, pH 7.0) and purified by HPLC (Model $110 \mathrm{~A}$; Beckman Instruments) with a $7.5 \times 75 \mathrm{~mm}$ TSK DEAE 5PW anion exchange column (BioRad Laboratories, Richmond, CA) using a linear salt gradient (0.1-0.8 M $\mathrm{NaCl}$ ) at a flow rate of $1 \mathrm{ml} / \mathrm{min}$ as previously described (13). To ensure adequate separation of ${ }^{35} \mathrm{~S}$-proteoglycans, HPLC-DEAE chromatographic peaks were rechromatographed on the HPLC-DEAE column before further characterization.

Characterization of glycosaminoglycan chains. ${ }^{35}$ S-glycosaminoglycans (GAG) were released from proteoglycan core protein by alkaline borohydrate reduction, neutralized, and desalted on Sephadex G-50 (Sigma Chemical Co.) columns as previously described (13). Under these conditions, greater than $95 \%$ of applied GAGs were recovered from the $\mathrm{V}_{\mathrm{o}}$ fractions. The heparan sulfate and chondroitin sulfate content of the recovered GAGs were determined by sequential nitrous acid deaminative cleavage $\left(22^{\circ} \mathrm{C}, 2 \mathrm{~h}\right)$ and chondroitinase $\mathrm{ABC}$ treatment $\left(0.3 \mathrm{U} / \mathrm{ml}, 37^{\circ} \mathrm{C}, 4 \mathrm{~h}\right)$, respectively, as previously described (13).

Western analysis. Microvascular endothelial cells were washed and lysed (15 min) on ice with lysis buffer (PBS, 1\% Triton X-100, $0.5 \%$ sodium deoxycholate, $1 \mathrm{mM}$ PMSF). Some aliquots of lysate supernatant were digested with chondroitinase $A B C\left(0.1 \mathrm{U} / \mathrm{ml}, 37^{\circ} \mathrm{C}\right.$, 4 h; Seikagaku America Inc., Rockville, MD) before electrophoresis. Proteins $(50 \mu \mathrm{g} / \mathrm{lane})$ were electrophoresed in $6-15 \%$ SDS-PAGE under nonreducing conditions (28), and electrophoretically transferred (45 min, $24 \mathrm{~V}$ ) to $0.2-\mu \mathrm{m}$ nitrocellulose membrane. Membranes were blocked with $10 \%$ dry milk in TTBS $(150 \mathrm{mM} \mathrm{NaCl}, 100$ $\mathrm{mM}$ Tris, $0.05 \%$ Tween 20$)\left(2 \mathrm{~h}, 21^{\circ} \mathrm{C}\right)$ and then incubated $\left(1 \mathrm{~h}, 21^{\circ} \mathrm{C}\right)$ with Hermes 3 (mouse anti-human CD44 antibody) (1:50 TTBS). After three washes $\left(5 \mathrm{~min}\right.$ each, $\left.21^{\circ} \mathrm{C}\right)$ with TTBS, the blot was incubated $\left(1 \mathrm{~h}, 21^{\circ} \mathrm{C}\right)$ with goat anti-mouse $\mathrm{IgG}$ antibody coupled to horseradish peroxidase (1:500 TTBS) and color developed by addition of substrate (3,3'-diaminobenzidine, Sigma Chemical Co; $40 \mathrm{mg} /$ $\mathrm{ml}$ ). Negative controls consisted of nitrocellulose membranes incubated with normal mouse serum followed by the anti-mouse IgG secondary antibody.

Immunoprecipitation and SDS-PAGE. Microvascular endothelial cells in $\log$ phase growth were released from culture flasks using 1 mM EDTA in PBS, pH 7.4, washed, and resuspended to a final concentration of $1 \times 10^{7}$ cells $/ \mathrm{ml}$ in PBS, $\mathrm{pH}$ 7.4, and placed on ice. Microvascular endothelial cells were surface labeled by the addition of 5 $\mathrm{mCi}^{125} \mathrm{I}$ to the cell suspension containing lactoperoxidase $(460 \mathrm{U} / \mathrm{ml}$ final concentration) and $\mathrm{H}_{2} \mathrm{O}_{2}(0.0017 \%$ final concentration $)$ and mixed ( $3 \mathrm{~min}$, on ice). The surface-labeled cells were washed, lysed $\left(30 \mathrm{~min}, 4^{\circ} \mathrm{C}\right)$ with solubilization buffer $(50 \mathrm{mM}$ Tris- $\mathrm{HCl}, \mathrm{pH} 7.4,50$ $\mathrm{mM} n$-octyl $\beta$-D glucopyranoside, $15 \mathrm{mM} \mathrm{NaCl}, 1 \mathrm{mM} \mathrm{CaCl}, 1 \mathrm{mM}$ $\mathrm{MgCl}_{2}, 1 \mathrm{mM} \mathrm{MnCl}, 1 \mathrm{mM}$ PMSF, $1 \mathrm{mM} \mathrm{NEM}, 100 \mu \mathrm{g} / \mathrm{ml}$ soybean trypsin inhibitor, $100 \mu \mathrm{g} / \mathrm{ml}$ leupeptin), and ultracentrifuged (36,500 $\mathrm{rpm}, 60 \mathrm{~min}, 4^{\circ} \mathrm{C}$ ) to remove insoluble material. The cell lysate was precleared $\left(3 \mathrm{~h}, 4^{\circ} \mathrm{C}\right)$ with rabbit anti-mouse IgG (Pelfreeze, Rogers, AR) coupled to protein A agarose beads, and incubated $\left(12 \mathrm{~h}, 4^{\circ} \mathrm{C}\right)$ with Hermes 3 (mouse anti-human CD44 antibody, kindly provided by Dr. Eugene Butcher, Stanford University, School of Medicine, Stanford, CA) coupled to rabbit anti-mouse IgG protein A agarose beads, and washed. Additional aliquots of precleared cell lysates were incubated with two mAbs (ICN Biomedicals, Inc.) that recognize the unsaturated bonds of 4-O sulfated and 6-O sulfated chondroitin sulfate residues that remain attached to the proteoglycan core protein after chondroitinase ABC digestion. Gel sample buffer was added to the washed beads and boiled ( $5 \mathrm{~min}$ ). To visualize CSPG core protein by autoradiography, ${ }^{125} \mathrm{I}$-labeled protein in the supernatants was digested with chondroitinase $\operatorname{ABC}\left(0.1 \mathrm{U} / \mathrm{ml}, 37^{\circ} \mathrm{C}, 4 \mathrm{~h}\right)$ and analyzed by $6-15 \%$ SDS-PAGE under nonreducing conditions (28). The gels were dried and used for autoradiography using Kodak XAR-5 film.

Reverse transcriptase (RT)-PCR. cDNA for PCR was synthesized by a random primer method as described by Bennett et al. (29). $1 \mu \mathrm{g}$ of microvascular endothelial cell total mRNA was incubated (5 min, $75^{\circ} \mathrm{C}$ ) with $2 \mu \mathrm{l}$ of $0.1 \mathrm{M}$ Hexamer (Gibco BRL). Subsequently, $4 \mu \mathrm{l}$ of $5 \times$ first strand buffer (Gibco BRL), $0.5 \mu \mathrm{l}$ of $0.1 \mathrm{M}$ DTT, $1 \mu \mathrm{l}$ of each 10mM dNTP's, and $1 \mu \mathrm{l}$ Superscript Plus (Gibco BRL) were added with DEPC-treated $\mathrm{H}_{2} \mathrm{O}$ to make a total vol of $20 \mu$. The mixture was incubated $\left(1 \mathrm{~h}, 37^{\circ} \mathrm{C}\right)$ and enzyme inactivated $\left(5 \mathrm{~min}, 95^{\circ} \mathrm{C}\right)$. PCR reactions were carried out in a total vol of $100 \mu$ l containing 20 $\mu \mathrm{l}$ of cDNA, $8 \mu \mathrm{l}$ of each $10 \mathrm{mM}$ dNTP's, $1 \mu \mathrm{l}$ of $20 \mathrm{pmol} / \mu \mathrm{l}$ of each primer, $8 \mu \mathrm{l} 10 \times$ PCR buffer, and $2.5 \mathrm{U}$ of Taq polymerase (Fisher Scientific Co., Pittsburgh, PA). Primers were added when the reaction mixture was at $95^{\circ} \mathrm{C}$. The cDNA was amplified in 35 cycles. The PCR amplification program was as follows: denaturation $(0.5 \mathrm{~min}$, $\left.95^{\circ} \mathrm{C}\right)$, annealing $\left(1.5 \mathrm{~min}, 56^{\circ} \mathrm{C}\right)$, extension $\left(1 \mathrm{~min}, 73^{\circ} \mathrm{C}\right)$, followed by a final extension $\left(10 \mathrm{~min}, 73^{\circ} \mathrm{C}\right)$. The oligonucleotides used as PCR primers were the CD44E3-FP and the CD44E16-RP primers as described by Bennett et al. (29). The CD44 variant exon primers were the pv2 through pv10 primers as previously described by van Weering et al. (30).

Fibrinogen affinity chromatography. For affinity chromatography, HPLC-DEAE purified fibrinogen was covalently coupled to ReactiGel according to manufacturers instructions (Pierce Chemical Co., Rockford, IL). Columns (30-ml bed vol) were equilibrated with 50 $\mathrm{mM}$ Tris, $\mathrm{pH}$ 6.8, 0.5\% CHAPS, $0.05 \mathrm{M} \mathrm{NaCl}, 0.01 \mathrm{M}$ 6-aminohexanoic acid, $0.1 \mathrm{mM}$ PMSF, $1.0 \mathrm{mM}$ NEM, and $0.02 \%$ azide. Detergent-extracted HPLC-DEAE partially purified ${ }^{35} \mathrm{~S}-\mathrm{CSPG}$ was applied to the fibrinogen affinity column, washed, and eluted with a linear salt gradient $(0.05-1.0 \mathrm{M} \mathrm{NaCl})$. To assure that the binding of CSPG was specific to fibrinogen, ${ }^{35} \mathrm{~S}-\mathrm{CSPG}$ was applied to a duplicate column prepared without fibrinogen. Recovery of radioactivity from this column was $>95 \%$.

Statistical analysis. All data were expressed as mean \pm SEM performed in triplicate unless otherwise indicated.

\section{Results}

Cell surface CSPG mediates microvascular endothelial cell invasion into a fibrin matrix. To examine the role of cell surface CSPG in mediating microvascular endothelial cell invasion, we used three-dimensional fibrin gels, using a modification of the technique described by Dvorak et al. (5). Microvascular endothelial cells layered on to the top surface of the fibrin formed a monolayer. After 4-7 d, cells invaded below the plane of the monolayer and formed extensive tubular networks within the fibrin matrix (Fig. $1 A$ ). Microscopic sections of the tubular networks within the fibrin gel revealed that the cells formed vascular-like structures containing lumens (Fig. $1 B$ ).

To evaluate the potential role of cell surface CSPG in mediating cell invasion into fibrin matrices, microvascular endothelial cell invasion was observed in the presence of $1.0 \mathrm{mM} \beta-\mathrm{D}$ xyloside. Microvascular endothelial cells cultured in the presence of $\beta$-D xyloside attached to the substratum and spread, forming monolayers on the surface of the fibrin gel. Analysis of their ability to invade the gel revealed that this function was 

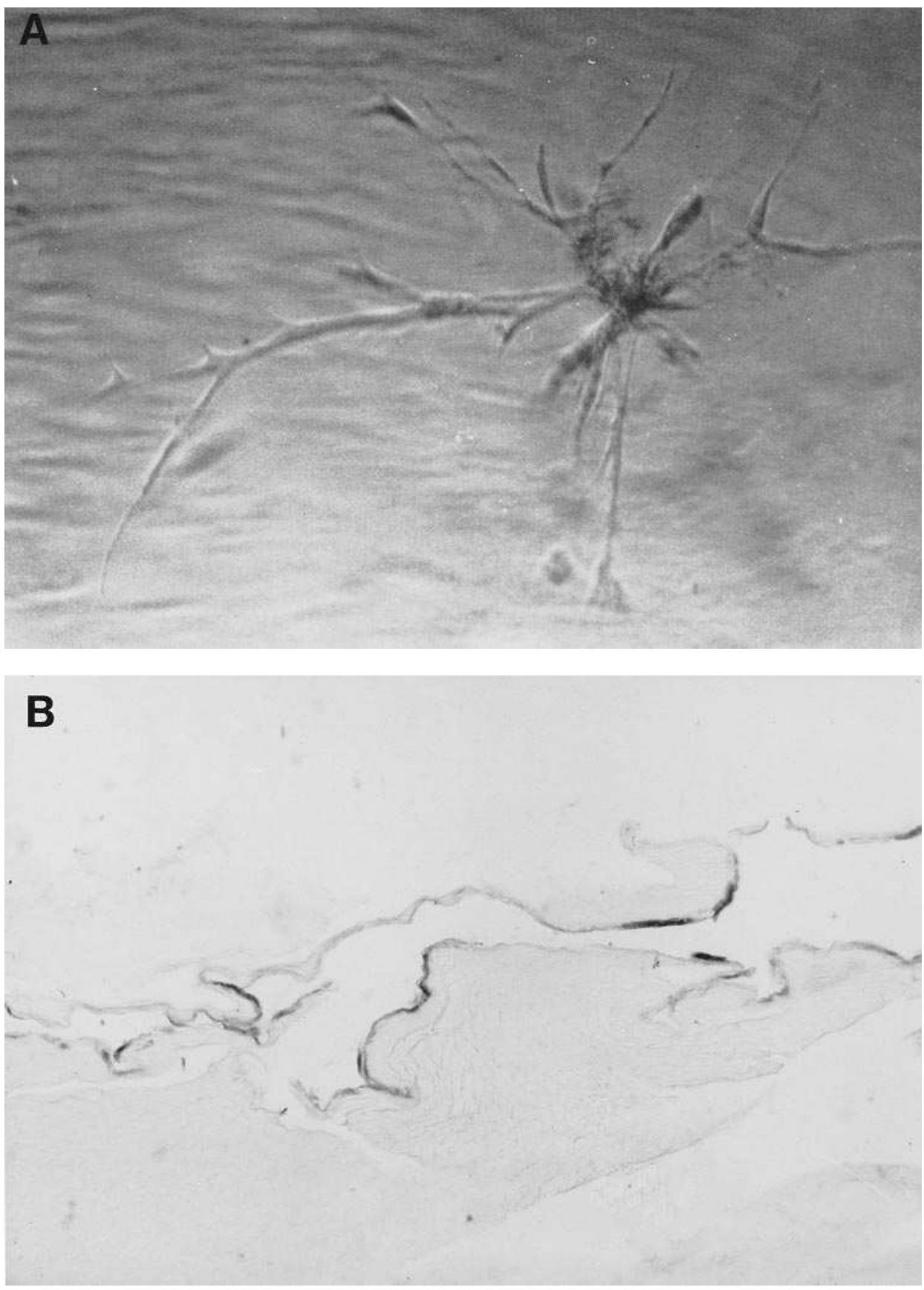

Figure 1. Wound microvascular endothelial cell invasion into a fibrin matrix. Fibrin gels were prepared (HPLC-DEAE purified fibrinogen, 3 $\mathrm{mg} / \mathrm{ml}$ ) as described in Methods. Wound microvascular endothelial cells were released from the flasks, resuspended in DME $+2.5 \%$ heatinactivated calf serum and added to the top surface of the fibrin gel. $(A)$ Shown is the phase-contrast microscopic appearance of wound microvascular endothelial cells invading the fibrin gel and forming tubular networks $(\times 130)$. (B) Microscopic section of a tubular network within the fibrin gel showing the wound microvascular endothelial cells forming lumens or vascular-like channels. The sections were stained with Bandeirea Simplicfolia agglutinin, a lectin stain specific for endothelial cells. inhibited by $\sim 95 \%$ at day 14 of gel culture (Fig. $2 A$ ). Wound microvascular endothelial cell invasion into fibrin was inhibited by $\beta$-D xyloside in a concentration dependent fashion (Fig. $2 B$ ). No inhibition of endothelial cell invasion was observed in the presence of $\alpha$-D xyloside, an inactive analogue of $\beta$-D xyloside which does not affect CSPG synthesis (Fig. $2 A$ ). Additionally, endothelial cell invasion into fibrin gels made from HPLC-DEAE purified fibrinogen and into hyaluronidase treated gels were also inhibited by $\beta$-D xyloside. These studies were performed to ensure that disruption of endothelial cell interaction with fibrin and not other ECM proteins contaminating the fibrin gels was the mechanism by which $\beta$-D xyloside inhibited invasion (data not shown).

As a control to determine whether $\beta$-D xyloside treatment was toxic to microvascular endothelial cells, the cells were pre- incubated with $1.0 \mathrm{mM} \beta$-D xyloside for $48 \mathrm{~h}$, enzyme released, washed, and layered onto the fibrin gels in the absence of additional $\beta$-D xyloside. The number of tubular networks formed by invading endothelial cells that had been exposed to $\beta$-D xyloside followed by withdrawal of the agent was actually increased compared to cells that had not been exposed to this drug $(150 \pm 28$ vs. $80 \pm 10)$. Additionally, $\beta$-D xyloside treated cells used for invasion assays were determined to be greater than $95 \%$ viable by trypan blue exclusion.

Cell surface CSPG mediates microvascular endothelial cell adhesion and migration to fibrinogen. Microvascular endothelial cells pretreated with $\beta$-D xyloside exhibited a $43 \%$ reduction in adhesion to fibrinogen as compared to untreated cells (Fig. $3 A$ ). $\alpha$-D xyloside, which does not affect CSPG synthesis, had no affect on endothelial cell adhesion. Endothelial cell ad- 
A

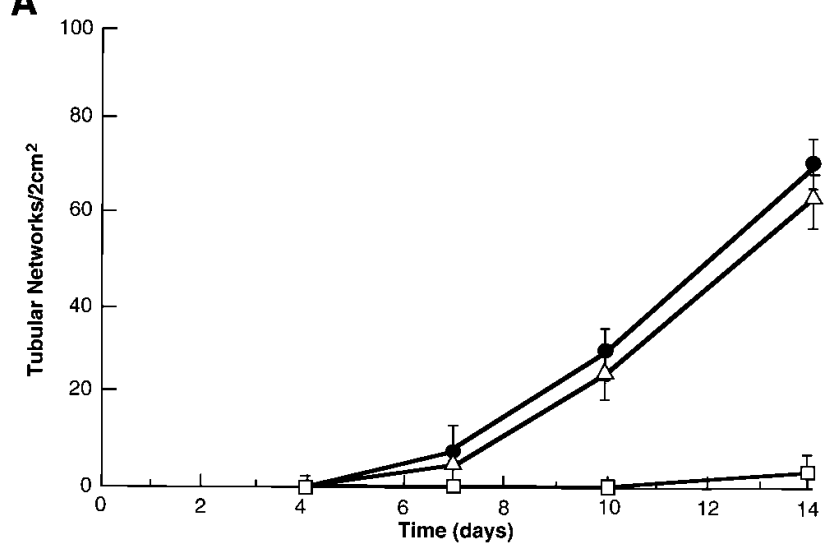

B

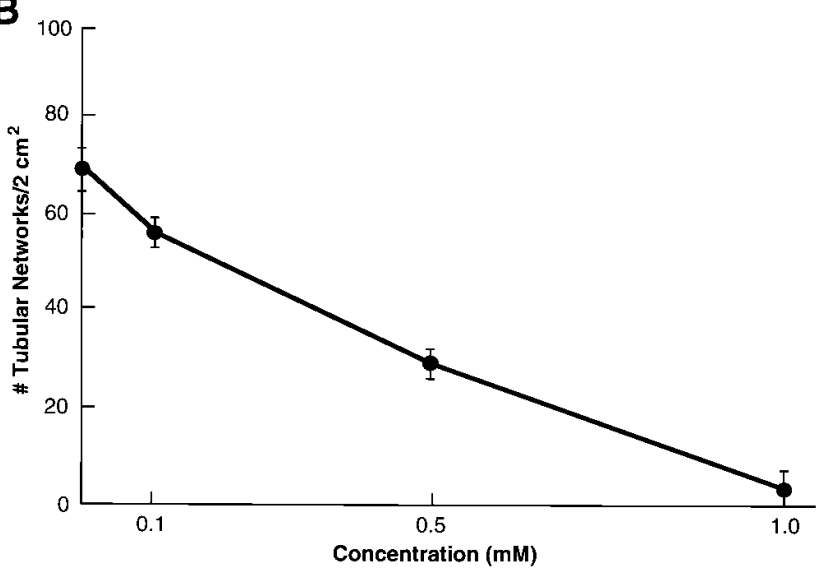

Figure 2. Invasion assay results: $\beta$-D xyloside inhibits microvascular endothelial cell invasion into fibrin gels. $(A)$ Wound microvascular endothelial cells were plated on the surface of the fibrin gels in the absence $(\bullet)$ or presence $(\square)$ of $1 \mathrm{mM} \beta$-D xyloside, and the presence of $1 \mathrm{mM} \alpha$-D xyloside $(\triangle)$. Shown are the number of tubular networks formed per $2 \mathrm{~cm}^{2}$ area of fibrin gel over a 14-d period. (B) The total number of tubular networks invading these gels at day 14 in the presence of varying concentrations $(0,0.1,0.5,1.0 \mathrm{mM})$ of $\beta$-D xyloside was determined.

hesion was inhibited by $\beta$-D xyloside in a concentration-dependent fashion. To further investigate the role of endothelial cell surface CSPG in mediating cell adhesion, we measured microvascular endothelial cell adhesion after pretreatment with chondroitinase $\mathrm{ABC}$, which cleaves the chondroitin sulfate sidechains from the core protein. Endothelial cell adhesion to fibrinogen after this treatment was inhibited by $33 \%$ (Fig. $3 B$ ). Combined with the results from the $\beta$-D xyloside adhesion assay, these results suggest that CSPG plays a role in mediating endothelial cell adhesion to fibrinogen.

To examine the role of cell surface CSPG in endothelial cell migration, the effects of $\beta$-D xyloside and chondroitinase $\mathrm{ABC}$ on microvascular endothelial cell motility were evaluated using the modified Boyden chamber. Endothelial cell motility on filters precoated with fibrinogen was inhibited by $65 \%$ in the presence of $1.0 \mathrm{mM} \beta$-D xyloside (Fig. $4 \mathrm{~A}$ ) and not affected by the inactive analogue, $\alpha$-D xyloside. Cell migration after treatment with chondroitinase $\mathrm{ABC}(0.1 \mathrm{U} / \mathrm{ml})$ was decreased by $70 \%$ on fibrinogen (Fig. $4 \mathrm{~B}$ ). Both $\beta$-D xyloside and chondroitinase $\mathrm{ABC}$ inhibited endothelial cell migration
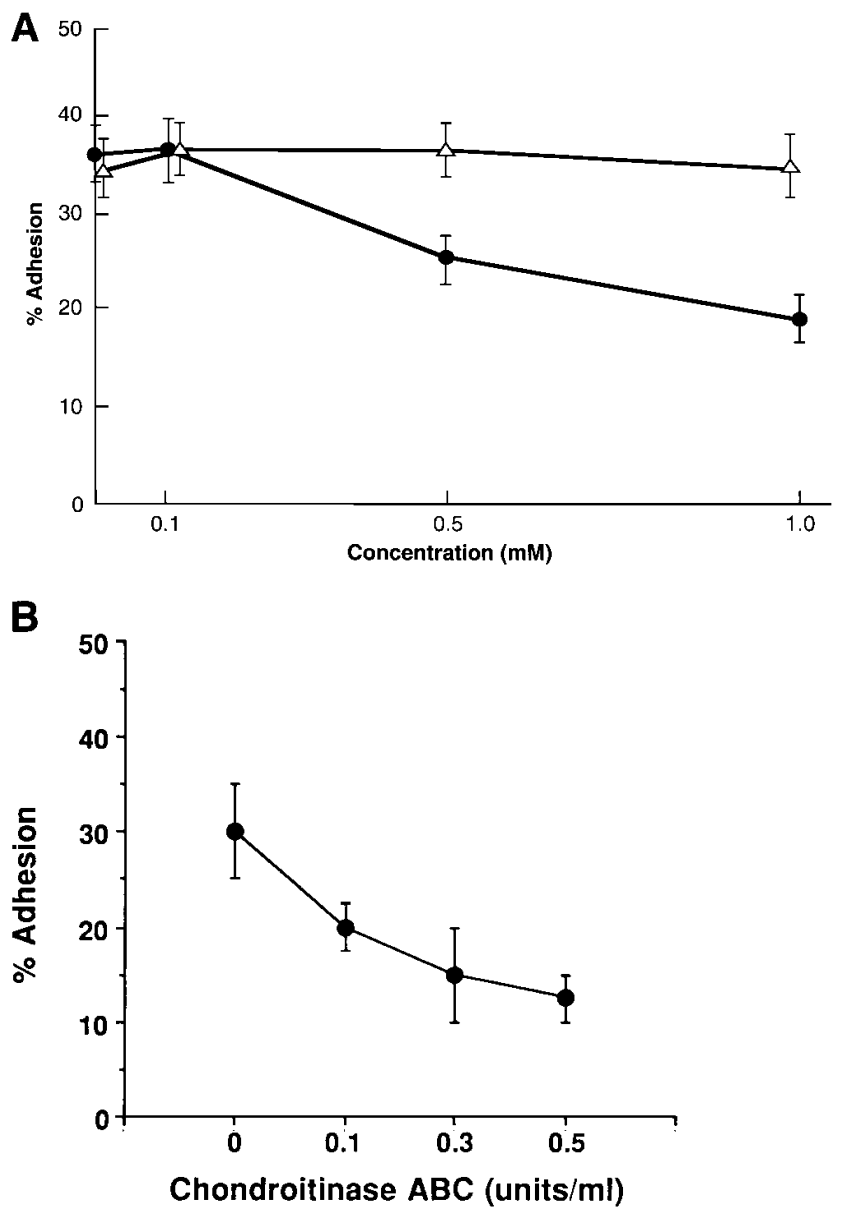

Figure 3. Wound microvascular endothelial cell adhesion to fibrinogen involves cell surface CSPG. $(A)$ Wound microvascular endothelial cells were pretreated for $48 \mathrm{~h}$ with varying concentrations of $\beta-\mathrm{D}$ xyloside (-) to inhibit the synthesis of CSPG. $\alpha$-D xyloside, which does not affect CSPG synthesis was used as a control $(\triangle)$. (B) Alternatively, cells were pretreated for $15 \mathrm{~min}$ with varying concentrations of chondroitinase $\mathrm{ABC}$ before the adhesion assay. Chondroitinase $\mathrm{ABC}$ was also included in the cell medium during the adhesion assay. Cells radiolabeled overnight with $\left[{ }^{3} \mathrm{H}\right]$ thymidine were released from the flasks and examined for their ability to adhere on substrata coated with varying concentrations of fibrinogen $(0.005-5 \mu \mathrm{M})$. Shown is microvascular endothelial cell adhesion to $0.5 \mu \mathrm{M}$ fibrinogen.

in a concentration dependent-fashion. These data suggest an important role for cell surface CSPG in mediating microvascular endothelial cell motility on fibrinogen.

Wound microvascular endothelial cell expression of CSPG. Based on the results of the functional assays implicating cell surface CSPG in endothelial cell adhesion and migration on fibrinogen and invasion into a fibrin matrix, wound microvascular endothelial cell proteoglycans were isolated and partially characterized. Proteoglycans were extracted from both wound microvascular endothelial cells in log phase growth (50-75\% confluent) and from cells confluent for $3 \mathrm{~d}$ to determine if the expression of proteoglycans were altered when cells became confluent.

Detergent extracts of ${ }^{35} \mathrm{SO}_{4}$-labeled cell cultures were chromatographed twice by HPLC-DEAE column chromatography. One predominant peak was obtained from both confluent and log phase wound microvascular endothelial cells which 

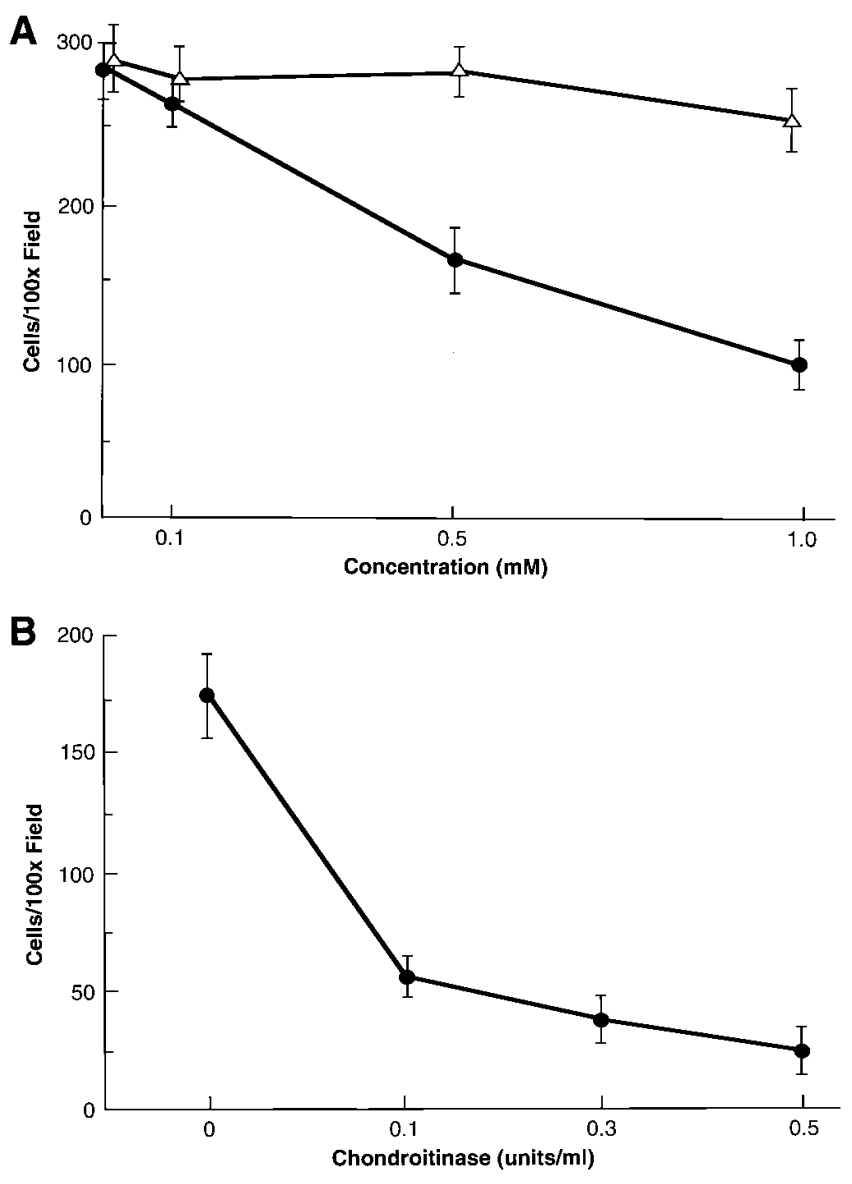

Figure 4. Wound microvascular endothelial cell migration on fibrinogen involves cell surface CSPG. $(A)$ Wound microvascular endothelial cells were pretreated for $48 \mathrm{~h}$ with varying concentrations of $\beta$-D xyloside ( $(-\alpha$-D xyloside was used as a control $(\triangle)$. (B) Alternatively, the cells were pretreated with varying concentrations of chondroitinase $\mathrm{ABC}$ before the migration assay. Cells were examined for their ability to migrate to the undersides of a filter that had been precoated with varying concentrations of fibrinogen (0.1-5 $\mu \mathrm{M}$ fibrinogen). Shown is microvascular endothelial cell migration to $0.5 \mu \mathrm{M}$ fibrinogen.

eluted from the HPLC-DEAE column at $0.38 \mathrm{M} \mathrm{NaCl}$ (Fig. 5 $A)$. Fractions from this peak were pooled and rechromatographed on HPLC-DEAE. ${ }^{35} \mathrm{~S}-\mathrm{CSPG}$ eluted at $0.38 \mathrm{M} \mathrm{NaCl}$ and contained $80-90 \%$ chondroitin sulfate as determined by chondroitinase $\mathrm{ABC}$ sensitivity and nitrous acid resistance and 10-20\% heparan sulfate as determined by nitrous acid sensitivity and chondroitinase $\mathrm{ABC}$ resistance (Fig. $5 B-D$ ). The remaining minor peak eluting at $0.2 \mathrm{M} \mathrm{NaCl}$ contained ${ }^{35} \mathrm{~S}$-glycoproteins and was not characterized further. These data indicate that CSPG is the predominant proteoglycan isolated from wound microvascular endothelial cells.

Microvascular endothelial cell CSPG core protein analysis. The relationship of microvascular endothelial cell CSPG to the previously described mouse melanoma cell CSPG core protein (CD44) was analyzed by Western blot analysis of cell lysates and by immunoprecipitation of ${ }^{125} \mathrm{I}$-surface proteins digested with chondroitinase ABC using Hermes 1 and Hermes 3 antiCD44 mAbs. The cell lysates and immunoprecipitated ${ }^{125}$ I-labeled protein(s) were analyzed by $6-15 \%$ SDS-PAGE under nonre- ducing conditions. Western analysis of undigested cell lysates revealed the presence of two broad smears ranging from $\sim 95$ to $110 \mathrm{kD}$ and $\sim 150$ to $>200 \mathrm{kD}$ (Fig. 6 A, lane $A$; brackets). After digestion of the cell lysates with chondroitinase ABC there was a downward shift in immunoreactivity with two bands present at 85 and $110 \mathrm{kD}$ (Fig. 6 A, lane $B$; arrowheads). This data is consistent with the interpretation that two CD44 core proteins are present which are modified by chondroitin sulfate. No immunoreactivity was present when the blots were incubated with normal mouse serum in place of the anti-CD44 antibody (data not shown).

In addition, two predominant proteins with molecular masses of 85 and $110 \mathrm{kD}$ were immunoprecipitated with the Hermes 1 and 3 anti-CD44 mAbs indicating an immunological relationship to CD44 (Fig. $6 B$, lane $B$, data shown for Hermes 3 antibody only) and confirming the Western analysis. A faint third band at $\sim 200 \mathrm{kD}$ was also immunoprecipitated. However, this protein was not immunoprecipitated by the anti-proteoglycan core protein antibodies (see below) and therefore probably does not represent a CSPG core protein. Multiple faint bands are visible in the undigested lane of CSPG proteins immunoprecipitated by anti-CD44 antibody (Fig. $6 B$, lane $A$ ) with the two most predominant at $\sim 97$ and $150 \mathrm{kD}$. These two bands roughly correspond to the smears present on Western analysis (Fig. $6 A$, lane $A$ ) and are therefore consistent with CD44 modified by chondroitin sulfate. However, the $97 \mathrm{kD}$ band is present in all lanes in the immunoprecipitation experiment, and therefore we are not certain whether this band represents CD44 without chondroitin sulfate, incompletely chondroitinase digested CD44, or nonspecific binding. Several other very faint bands at $<85$ were immunoprecipitated with both the anti-CD44 antibody and anti-proteoglycan core antibodies and were present in all lanes and likely represent nonspecific binding. As a negative control, rabbit anti-mouse IgG antibody coupled to protein A agarose beads failed to bind the proteoglycan core proteins (data not shown). Of note, $\sim 25 \%$ of radiolabeled CSPG was immunoprecipitated by the antiCD44 antibodies indicating that at a minimum, $25 \%$ of total CSPG is CD44-related CSPG.

To confirm that the two proteins immunoprecipitated by antiCD44 antibodies were proteoglycan core proteins, ${ }^{125}$ I surfacelabeled proteins were detergent extracted and immunoprecipitated using two mouse mAbs that recognize the unsaturated bonds of 4-O and 6-O sulfated chondroitin sulfate residues (stubs) that remain attached to the proteoglycan core protein after chondroitinase ABC digestion. The resulting autoradiogram showed that the two CD44-related CSPG proteins were recognized by the monoclonal proteoglycan core antibodies after chondroitinase $\mathrm{ABC}$ digestion with exactly the same molecular masses of 85 and $110 \mathrm{kD}$ (Fig. $6 \mathrm{~B}$, lane $C$ ). As mentioned above, a faint band at $97 \mathrm{kD}$ is present in the lane showing undigested CSPG immunoprecipitated with the $\mathrm{mAbs}$ that recognize digested core protein (Fig. $6 B$, lane $D$ ). We are unsure whether this band represents some reactivity of the antibodies with core protein or nonspecific binding. These data demonstrate that two predominate CD44 core proteins are present in wound microvascular endothelial cells.

Analysis of CD44 $\mathrm{mRNA}$ transcripts in wound microvascular endothelial cells. RT-PCR was performed to determine which mRNA transcripts encoding for different CD44 isoforms are present in wound microvascular endothelial cells. Consistent with the Western analysis and immunoprecipita- 

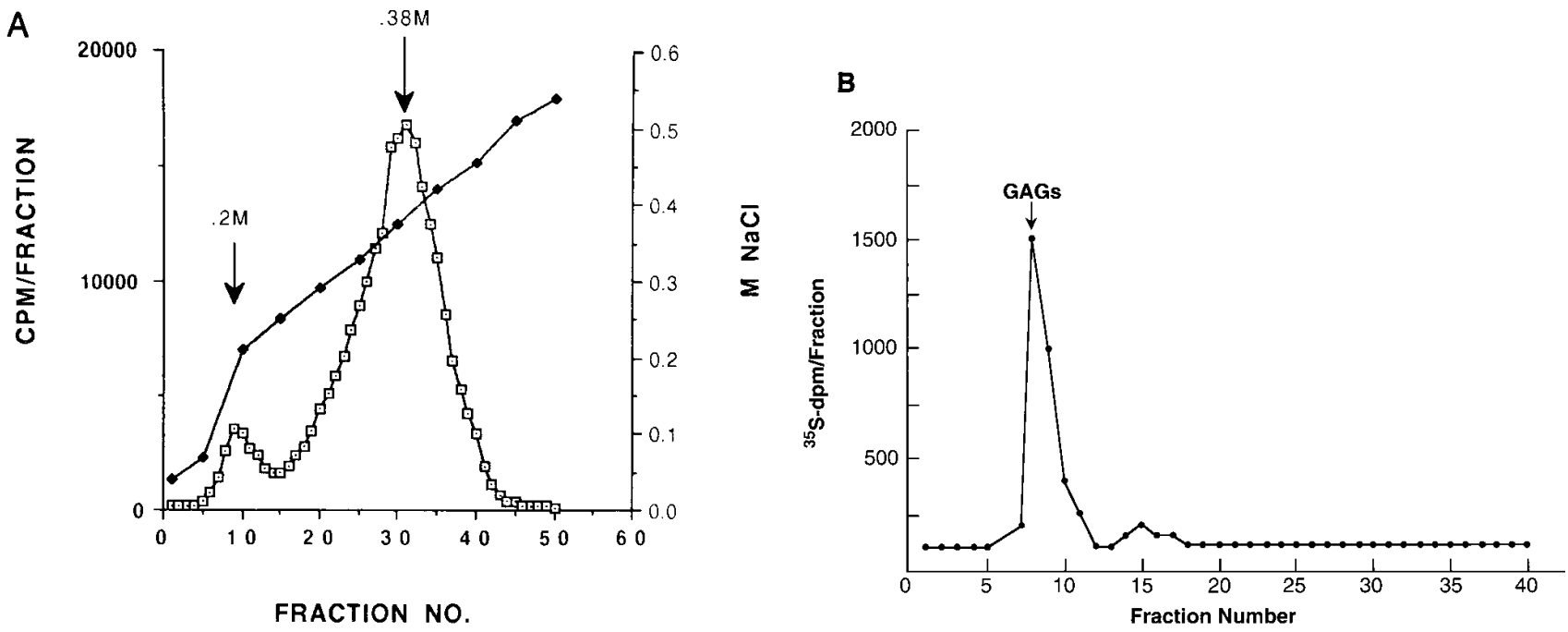

FRACTION NO.
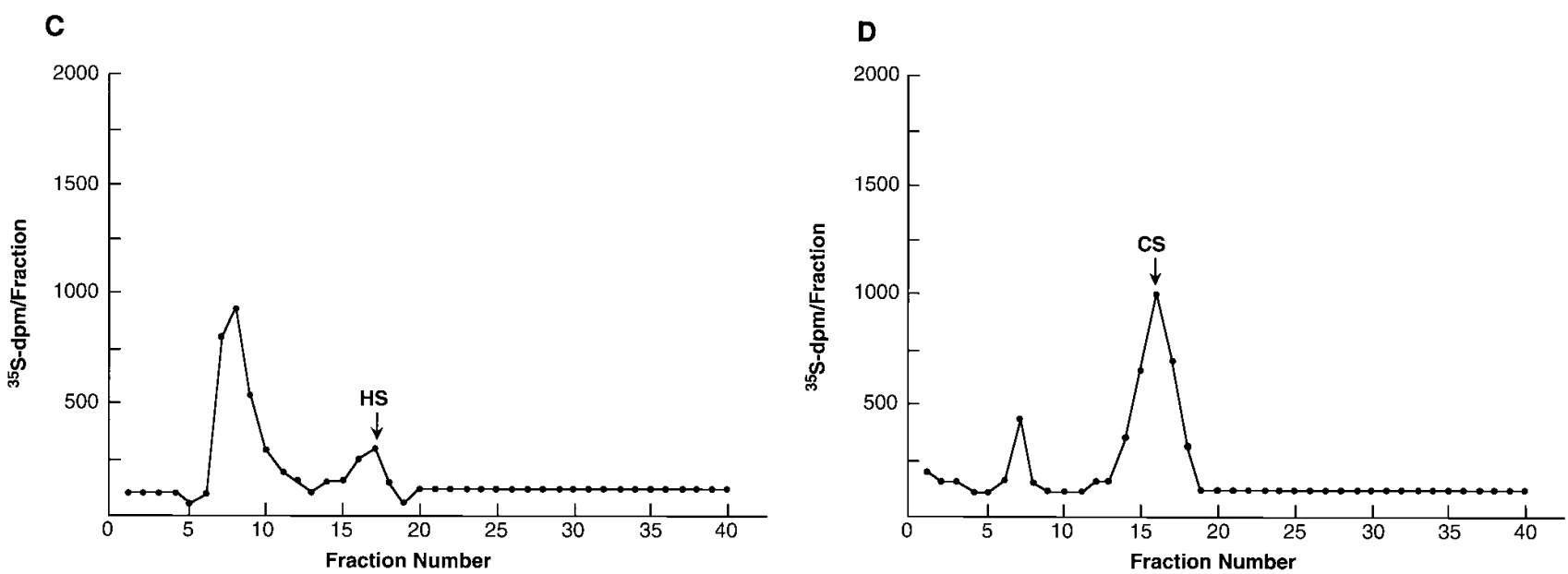

Figure 5. Proteoglycan profile of wound microvascular endothelial cells. Microvascular endothelial cells express predominately CSPG. $(A)$ Detergent-extracted ${ }^{35} \mathrm{~S}$-proteoglycans were dialyzed into DEAE buffer $(0.15 \mathrm{M}$ Tris, $6.0 \mathrm{M}$ urea, $0.1 \mathrm{M} \mathrm{NaCl}, 0.01 \mathrm{M}$ EDTA, $0.01 \mathrm{M}$ 6-aminohexanoic acid, $0.2 \%$ Triton X-100, $0.1 \mathrm{mM}$ PMSF, $\mathrm{pH}$ 7.0) and purified by HPLC with a DEAE anion exchange column using a linear salt gradient. Radioactivity was monitored for each $1 \mathrm{ml}$ fraction $(\square)$ and the salt gradient was monitored by conductivity measurements $(\diamond)$. The HPLCDEAE chromatographic peak eluting at $0.38 \mathrm{M} \mathrm{NaCl}$ was rechromatographed on the HPLC-DEAE column before further characterization. (B) Purified CSPG underwent alkaline $\beta$-elimination to release ${ }^{35}$ S-GAGs. Shown is the ${ }^{35}$ S-GAG Protein G Sepharose $4 \mathrm{~B}$ chromatographic profile. $(C$ and $D)$ Radiolabeled GAGs were then chromatographed on a Protein G Sepharose 4B column after nitrous acid deaminative cleavage $(C)$ and chondroitinase $\mathrm{ABC}$ treatment $(D)$ to determine the heparan sulfate and chondroitin sulfate content of the ${ }^{35} \mathrm{~S}-\mathrm{GAGs}$, respectively.

tion studies showing two predominant CD44 isoforms, RTPCR using PCR primers located in the common exons E3 and E16 generated two PCR products of $\sim 450$ and 550 bp (Fig. 7). The approximate 450-bp product is the predicted size (469 bp) for the "standard" isoform of CD44 (CD44H), which corresponds to the $85-\mathrm{kD}$ protein.

RT-PCR was also used to examine expression of CD44 transcripts containing variant exons. The variant exon primers pv2 through pv10 were used as forward primers and the E16 PCR primer was used as the reverse primer. Using the pv3-2 primer which is downstream of the alternate acceptor site in exon 3, a PCR product of $\sim 200$ bp was generated. No other transcripts were present using other variant exon primers. The approximate 200-bp product is the predicted size for variant exon 3 (V3 alternate acceptor site) plus E16. This corresponds to the 550-bp product present using the E3 and E16 primers and represents a PCR product which begins in constant exon 3 , ends in constant exon 16, and contains the variant exon 3 (alternate acceptor site). Importantly, variant exon 3 contains the Ser-Gly-Ser-Gly sequence which is a potential glycosaminoglycan attachment site (29). Negative controls consisting of PCR of primers only (no DNA) and PCR of RNA (no reverse transcriptase reaction) yielded no PCR products. This indicates that the higher mol wt CD44 isoform present in the immunoprecipitation experiments $(110-\mathrm{kD}$ protein) is encoded by a mRNA transcript containing variant exon 3.

Anti-CD44 antibody blocks endothelial cell migration on fibrinogen. Anti-CD44 mAb was used to assess the role of CD44 in mediating endothelial cell motility on fibrinogen. Wound microvascular endothelial cells preincubated with anti-CD44 $\mathrm{mAb}$ exhibited a dose-dependent reduction in migration on fibrinogen (Fig. 8). At the two highest concentrations (10 and 20 $\mu \mathrm{g} / \mathrm{ml}$ ) of $\mathrm{mAb}$ tested, microvascular endothelial cell migration was completely inhibited. As controls, normal mouse IgG 


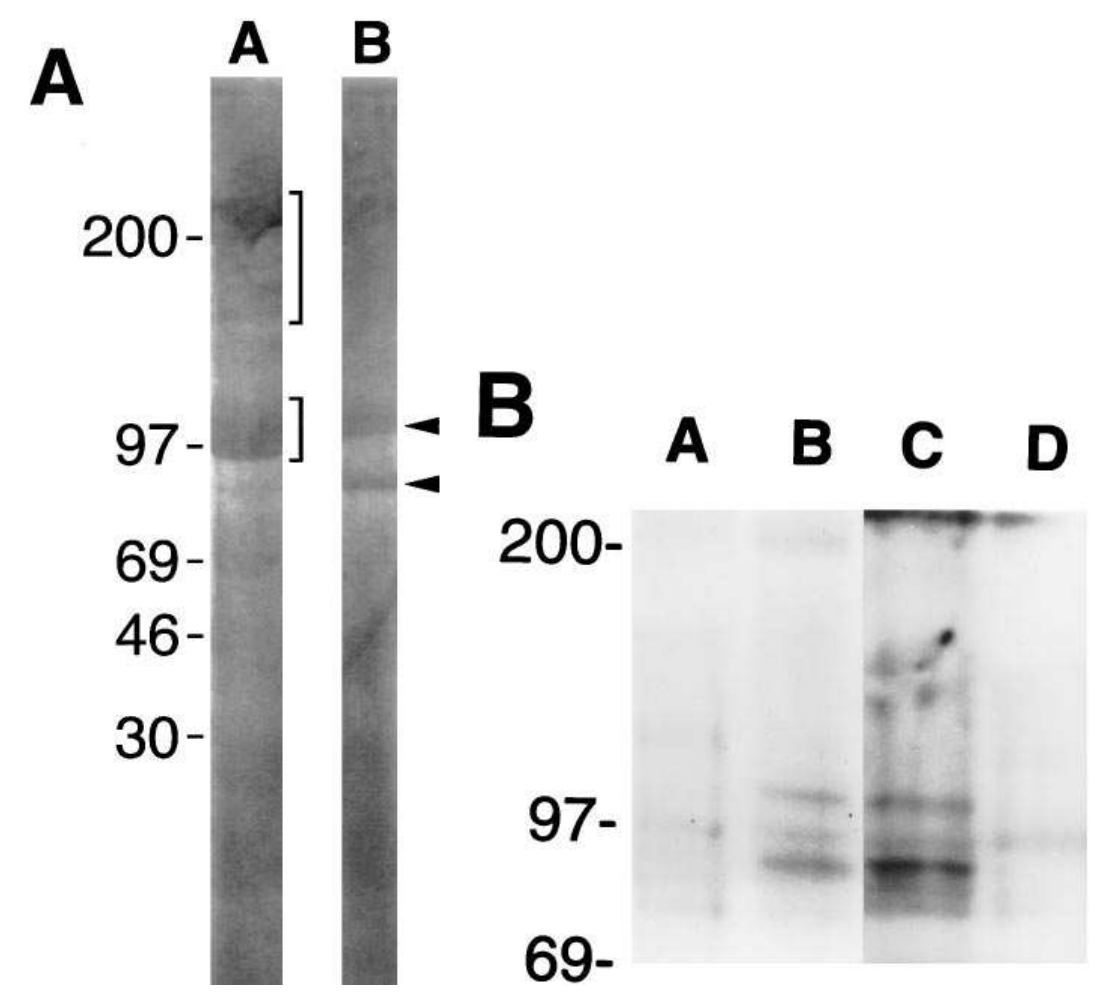

Figure 6. Identification of two CSPG core proteins with molecular masses of 85 - and $110-\mathrm{kD}$ by Western analysis and immunoprecipitation with CD44 mAbs. To determine the molecular mass of the CSPG core protein(s), and to analyze the core proteins for antigenic similarity to CD44, Western analysis of microvascular endothelial cell lysates was performed $(A)$. To confirm Western analysis data, ${ }^{125}$ I surface-labeled proteins were detergent-extracted and immunoprecipitated using anti-CD44 mAbs $(B$, lanes $A$ and $B$ ) and $m A b s$ that recognize chondroitin sulfate residues attached to the core protein after chondroitinase treatment $(B$, lanes $C$ and $D)$. The cell lysates and immunoprecipitated proteins were analyzed by $6-15 \%$ SDS-PAGE under nonreducing conditions. ( $A$, lane $A$ ) Western analysis of undigested cell lysates. $(A$, lane $B)$ Western analysis of chondroitinase ABC digested cell lysates. $B$, lane $A$ contains undigested CSPG Hermes 3 (mouse antihuman $\mathrm{CD} 44 \mathrm{mAb}$ ) immunoprecipitated proteins. $B$, lane $B$ contains proteins immunoprecipitated by Hermes 3 after chondroitinase $\mathrm{ABC}$ digestion. $B$, lane $C$ contains proteoglycan core proteins immunoprecipitated by the monoclonal antibodies that recognize the unsaturated bonds of chondroitin sulfateassociated uronic acid residues that remain on the core protein after chondroitinase $\mathrm{ABC}$ digestion. $B$, lane $D$ contains undigested CSPG proteins immunoprecipitated with the anti-proteoglycan core protein antibodies. antibody and an anti- $\alpha_{2} \beta_{1}$ integrin $\mathrm{mAb}$ (mediates binding to collagen) were substituted for the anti-CD44 antibody. No reduction in microvascular endothelial cell migration on fibrinogen occurred when the microvascular endothelial cells were preincubated with control antibodies.

HPLC-DEAE partially purified microvascular endothelial cell CSPG binds fibrinogen. To directly assess whether mi- crovascular endothelial cell CSPG binds fibrinogen, detergentextracted HPLC-DEAE partially purified ${ }^{35}$ S-CSPG was applied to a fibrinogen affinity column. Rabbit fibrinogen was purified by HPLC-DEAE chromatography to remove small quantities of contaminating fibronectin. HPLC-DEAE partially purified CSPG bound to the fibrinogen affinity column and eluted in a relatively broad band from the column by $0.45 \mathrm{M}$
A

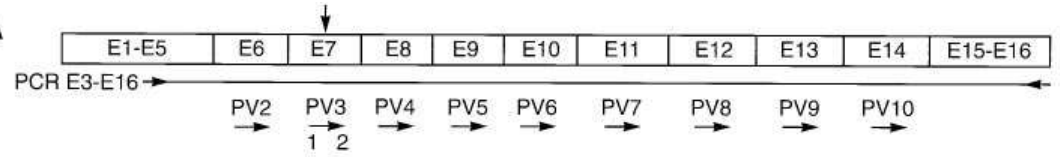

B

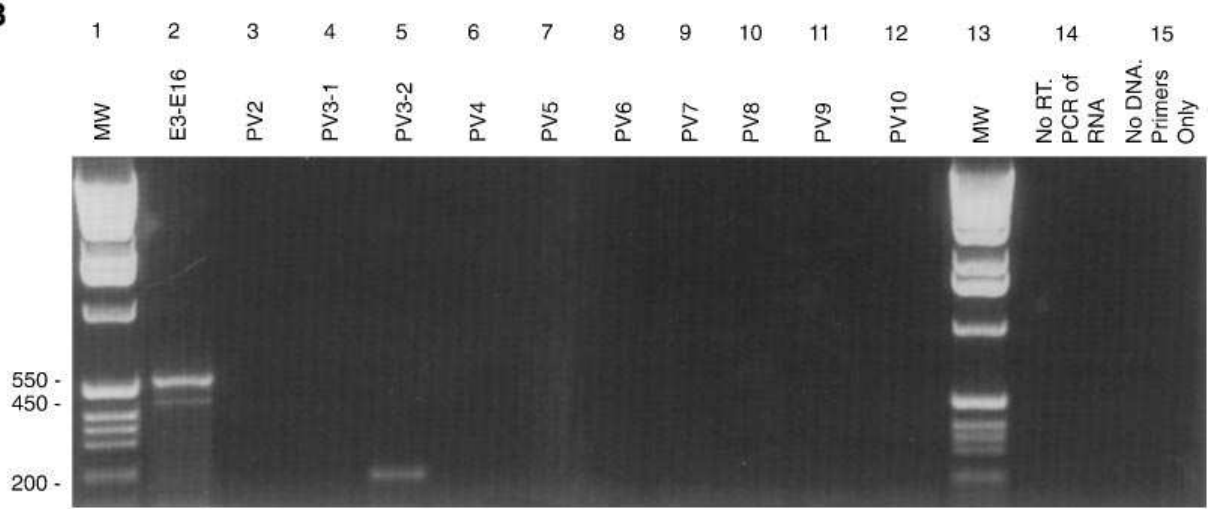

Figure 7. Expression of CD44 RNA transcripts in wound microvascular endothelial cells. $(A)$ Line drawing representation of the extracellular domains of CD44 based on the exon map of Screaton et al. (31). E1-E5 and E15E16 represent constant CD44 exons. E6-E14 represent potential alternatively spliced exons. E3 represents the constant exon forward primer and E16 represents the constant exon reverse primer used to generate the PCR products in lane 2 . The arrow above E7 represents the alternate acceptor site in variant exon V3. PV2-PV10 represent forward primers for each of the variable exons that were used to generate RT-PCR bands. $(B)$ RTPCR was performed on wound microvascular endothelial cells. PCR products were fractionated on a $2 \%$

agarose gel and stained with ethidium bromide. Lanes 1 and 10 contain the 1-kb DNA ladder. Lane 2 contains the PCR products for the constant to constant exon primers (E3-E16). Lanes 3-12 contain the PCR products for each of the variant exon primers. Lanes 14 and 15 are negative controls. 


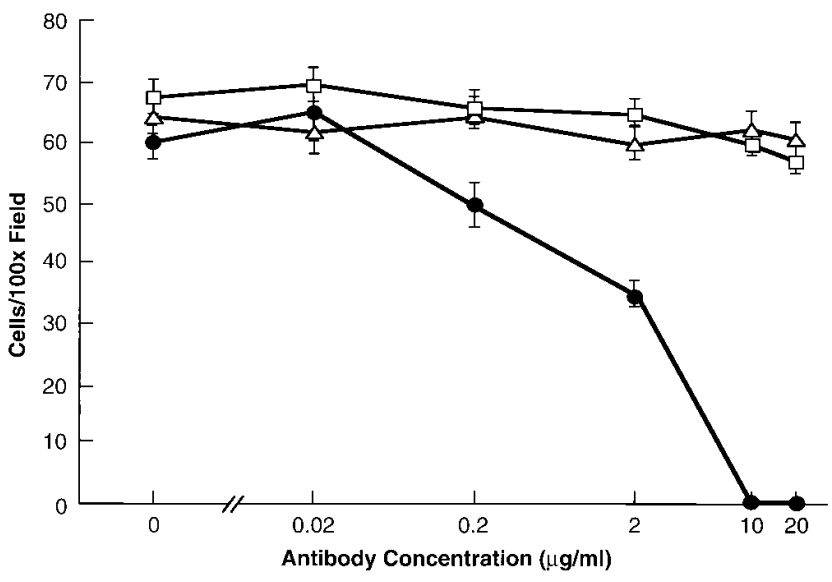

Figure 8. Wound microvascular endothelial cell migration on fibrinogen is inhibited by anti-CD44 mAb. Microvascular endothelial cells were preincubated for $30 \mathrm{~min}$ with varying concentrations of a mouse anti-human CD44 mAb. Endothelial cell migration to the undersides of filters coated with varying concentrations of fibrinogen $(0.1-5 \mu \mathrm{M})$ were assessed using modified Boyden chambers in the continued presence of CD44 antibody $(\bullet)$. Normal mouse $\operatorname{IgG}$ antibody $(\triangle)$ and anti- $\alpha_{2} \beta_{1}$ integrin $\mathrm{mAb}(\square)$ were used as controls. Shown is wound microvascular endothelial cell migration to $0.5 \mu \mathrm{M}$ fibrinogen quantified as the number of cells migrating per $\times 100$ field.

$\mathrm{NaCl}$ (Fig. 9). CSPG eluting from the column was verified as authentic by nitrous acid resistance and chondroitinase ABC sensitivity. In addition, ${ }^{35} \mathrm{~S}-\mathrm{CSPG}$ was applied to a sham column prepared without fibrinogen. Recovery of radioactivity from this column was $95 \%$ indicating that the binding of CSPG to fibrinogen was specific.

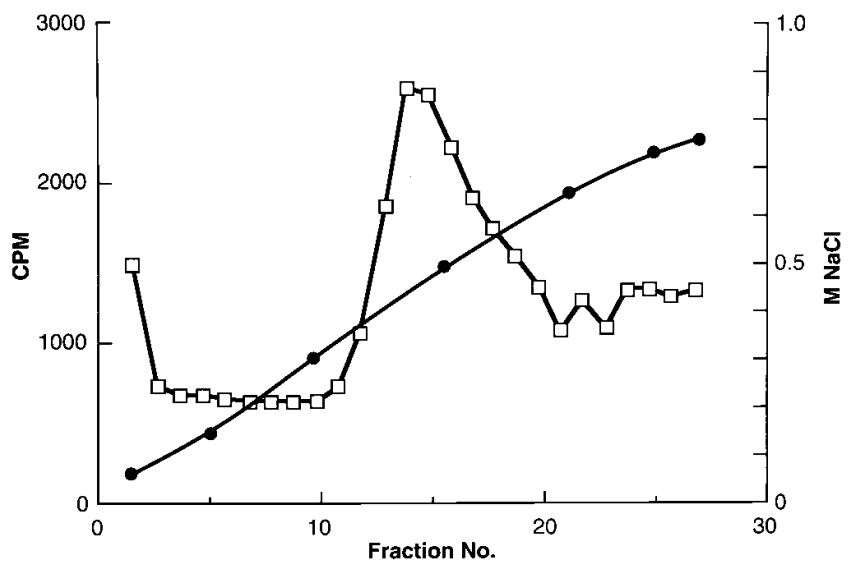

Figure 9. Wound microvascular endothelial cell CSPG binds to a fibrinogen affinity column. Detergent extracted HPLC-DEAE partially purified ${ }^{35} \mathrm{~S}-\mathrm{CSPG}$ was applied to a fibrinogen affinity column equilibrated with $50 \mathrm{mM}$ Tris, $\mathrm{pH} 6.8,0.5 \%$ CHAPS, $0.05 \mathrm{M} \mathrm{NaCl}$, 0.01 M 6-aminohexanoic acid, 0.1 mM PMSF, 1.0 mM NEM, 0.02\% azide. Rabbit fibrinogen was purified by HPLC-DEAE chromatography to remove small amounts of contaminating fibronectin. The column was eluted with a linear salt gradient. Radioactivity was monitored for each 1-ml fraction ( $\square$ ), and the salt gradient was monitored by conductivity measurements $(\bullet)$.

\section{Discussion}

Microvascular endothelial cell invasion into the fibrin provisional matrix is an integral component of angiogenesis during wound and tissue repair after injury. Cell surface matrix receptors, which interact with ECM proteins like fibrin, mediate the adhesion and migration of the cell into the ECM. The central finding in this paper is that a CD44-related CSPG cell surface matrix receptor is capable of mediating wound microvascular endothelial cell migration on fibrinogen and invasion into a fibrin matrix. By inhibiting the synthesis of CSPG with $\beta$-D xyloside, a reduction in microvascular endothelial cell adhesion and migration on fibrinogen and invasion into a three-dimensional fibrin gel was observed. Similarly, microvascular endothelial cell adhesion and migration on fibrinogen was significantly decreased by pretreatment with chondroitinase ABC which enzymatically cleaves chondroitin sulfate from the core protein. We have also determined that wound microvascular endothelial cells express CSPG as their predominant proteoglycan and that the CSPG contains two core proteins with molecular masses of 85 and $110 \mathrm{kD}$. Each of these core proteins can be immunoprecipitated with two different CD44 mAbs indicating antigenic similarity with CD44. PCR studies indicate that wound microvascular endothelial cells express both the standard $(\mathrm{CD} 44 \mathrm{H})$ isoform and an isoform containing variably spliced exon V3. In addition, anti-CD44 antibody blocks endothelial cell migration on fibrinogen. Furthermore, partially purified wound microvascular endothelial cell CSPG is capable of binding purified fibrinogen. These data suggest that wound microvascular endothelial cell CD44-related CSPG is capable of binding fibrinogen/fibrin thereby mediating endothelial cell adhesion, migration, and invasion into the fibrin matrix.

CD44-related CSPG mediates cell motility. CD44 is a transmembrane glycoprotein that may mediate tumor cell migration. The CD44 gene contains 19 exons, 12 of which may be alternatively spliced leading to the existence of multiple isoforms of CD44 (31). The diversity of CD44 is further amplified by the differential use of GAG attachment sites on its extracellular domain. Various isoforms of CD44 have been associated with enhanced migration and invasion of transformed cells (22-25). For example, we have previously shown that mouse melanoma cell invasion into type I collagen gels is mediated by CSPG containing an 110-kD CD44 core protein (13).

Several lines of evidence link cell surface CSPG with the motility of endothelial cells during wound/tissue repair. First, wounded large vessel endothelial cell cultures rapidly alter their proteoglycan synthesis from heparan to chondroitin sulfate, which coincidently occurs with the onset of migration (11). Second, immunohistochemical analysis of granulation tissue in healing cutaneous wounds showed intense staining for CSPG. Third, proteoglycans extracted from healing wounds after in situ labeling with ${ }^{35} \mathrm{SO}_{4}$ contained more CSPG than normal dermis and had longer glycosaminoglycan chondroitin sulfate sidechains. Finally, alterations of proteoglycan synthesis associated with granulation tissue formation correlates with cell proliferation and migration (32). These data suggest that alterations in CSPG synthesis in granulation tissue may play an important role in regulating such cellular functions as migration and invasion during wound/tissue repair. This is in agreement with our finding that wound microvascular endothelial cells express the majority of their cell surface proteoglycan as 
CSPG and that cell surface CSPG is important in mediating migration and invasion into the fibrin matrix.

Acquisition of an endothelial cell migratory phenotype may be important for angiogenesis to occur. Studies indicate that endothelial cells increase their proteolytic activity (33-36), alter their fibronectin synthesis (37), and express specific migration-associated cell surface glycoproteins (11) during wound repair. These modifications are thought to facilitate cell movement. In support of the hypothesis that endothelial cells express a specific phenotype during migration are a series of in vivo and in vitro experiments. First, in vivo work indicates that fibrin gels (but not collagen or agarose) implanted into the subcutaneous tissue of guinea pigs are capable of inducing angiogenesis (4). Presumably those endothelial cells invading the fibrin matrix from the connective tissue space express the migratory phenotype. In contrast, prior in vitro investigations as well as our own unpublished observations have shown that large vessel endothelial cells, in the absence of exogenous stimuli, are incapable of invading the fibrin gel (38). However, as shown in the current study, wound microvascular endothelial cells, which express CSPG as their predominant cell surface proteoglycan, are fully capable of invading into the fibrin matrix and forming vascular-like networks without exogenous stimulation. Our finding that microvascular endothelial cell CSPG is capable of binding fibrinogen coupled with Dvorak's work indicating that fibrin is capable of eliciting an angiogenic response suggests that CD44-related CSPG/fibrin interaction may play an important role in directing endothelial cell migration into the fibrin provisional matrix during wound repair. Our migration assays, which demonstrate that anti-CD44 antibody blocks migration on fibrinogen, support the concept of a specific CD44-related CSPG-fibrinogen interaction. However, since CD44-related CSPG represents a portion of total microvascular endothelial cell CSPG we cannot be certain that CD44-related CSPG binds fibrinogen. This requires further investigation. These data suggest that wound microvascular endothelial cells assume a migratory phenotype.

It is possible that the expression of CD44-related CSPG on the cell surface may be an important component of the migration phenotype. Our data indicate that microvascular endothelial cells express predominantly CSPG and that the CSPG contains two CD44 core proteins, the standard or $85-\mathrm{kD}$ isoform and an $\sim 110-\mathrm{kD}$ isoform. Western analysis shows two broad smears of immunoreactivity at $\sim 95-110 \mathrm{kD}$ and 150 to $>200$ $\mathrm{kD}$ in undigested cell lysates which shift downward after chondroitinase digestion resulting in the $85-$ and $110-\mathrm{kD}$ bands. This data is consistent with the interpretation that CD44 is modified by chondroitin sulfate. Immunoprecipitation data indicate that the chondroitinase digested 85- and 110-kD CD44 proteins are proteoglycan core proteins. Interestingly, the 97$\mathrm{kD}$ band, which is present as a prominent broad smear in the chondroitinase undigested lane in the Western blot, is present in all lanes (both chondroitinase digested and undigested) in the immunoprecipitation experiment. Because there is a downward shift in immunoreactivity after chondroitinase digestion in the Western analysis, this suggests that the $97-\mathrm{kD}$ band is CD44 modified by chondroitin sulfate. However, because the $97-\mathrm{kD}$ band is present in all lanes in the immunoprecipitation experiment, this band could also represent CD44 without chondroitin sulfate, CD44 partially modified by chondroitin sulfate, or nonspecific binding. Further work is necessary to clarify this issue. In addition, our PCR studies demon- strate that microvascular endothelial cells express both the standard $(\mathrm{CD} 44 \mathrm{H})$ isoform encoding the $85-\mathrm{kD}$ isoform of CD44 and an isoform containing the variably spiced exon V3 encoding the $\sim 110$-kD CD44 isoform. Importantly, exon V3 contains the Ser-Gly-Ser-Gly sequence which serves as a potential glycosaminoglycan attachment site (29). Additional glycosaminoglycan attachment sites are also present in the constant regions of CD44. Therefore, since wound microvascular endothelial cells express CSPG on their surface it seems plausible that these glycosaminoglycan attachment sites are occupied by chondroitin sulfate. In contrast however, a prior study has determined that large vessel endothelial cells express only the standard $(\mathrm{CD} 44 \mathrm{H})$ isoform of CD44 encoding the $85-\mathrm{kD}$ protein (29). Additionally, large vessel endothelial cells express predominantly heparan sulfate on their surface and only switch their proteoglycan synthesis from heparan to chondroitin sulfate as migration is initiated after wounding (11). Collectively these data support the hypothesis that the wound microvascular endothelial cell migratory phenotype is characterized by the presence of the 85 - and 110-kD CD44 isoforms which are modified by the addition of chondroitin sulfate.

Insights into the mechanism of CD44-related CSPG-mediated cell motility. The precise mechanism by which CD44-related CSPG mediates cell motility is not completely understood. However, as demonstrated in this study, anti-CD44 mAbs block endothelial cell migration, suggesting that CD44 core protein is involved in cell migration. The ability of CD44 to bind multiple extracellular proteins and therefore function as a matrix adhesion receptor is likely important in facilitating cell movement. CD44 is a matrix receptor for hyaluronate (39), fibronectin (40), type I collagen $(13,41)$, and the adhesion and migration assays in our current study provide evidence that CD44-related CSPG also interacts with fibrinogen. The importance of CD44 as an ECM adhesion receptor is illustrated by a recent study in which mouse fibroblasts transfected with a primate CD44 gene acquired a new adhesive phenotype (42). Furthermore, CD44 has been shown to associate with the cytoskeleton $(14,15,43,44)$ further linking it with cell adhesion and migration.

Chondroitin sulfate on the CD44 core protein may also play a role in facilitating cell migration. We have previously shown that chondroitin sulfate binds ECM proteins such as collagen (13). Other work has shown that CSPG is present on microspikes on the cell surface which mediate cell attachment to the ECM (12). Our adhesion and migration assays in which chondroitin sulfate is cleaved from the core protein by chondroitinase resulting in reduced adhesion and migration suggest that chondroitin sulfate is involved in cell attachment and motility. Further support for this hypothesis comes from the finding that endothelial cell adhesion and migration to fibrinogen were inhibited to a similar degree by both chondroitinase and $\beta$-D xyloside in a concentration dependent fashion, suggesting that the degree of removal of chondroitin sulfate from the core protein corresponded with the observed decreases in adhesion and migration.

Interestingly, we have found that when CSPG function is blocked by either $\beta$-D xyloside or chondroitinase ABC treatment in the short term adhesion assay, the degree of inhibition of endothelial cell adhesion to fibrinogen was the same, $50 \%$. The fact that only $50 \%$ inhibition of adhesion was seen despite high concentrations of $\beta$-D xyloside or enzyme suggests that other receptors such as integrins are involved in microvascular 
endothelial cell adhesion to fibrinogen. Furthermore, in the invasion assay, the cells were capable of adhering to the surface of the fibrin gel even in the presence of $\beta$-D xyloside but were unable to invade the gel. Of note, the apparent discrepancy between the short term adhesion assay where endothelial cell adhesion to fibrinogen can be partially inhibited vs the long term invasion assay where endothelial cells are capable of attaching to fibrin may be explained by the use of alternate adhesion receptors. Therefore, in addition to CSPG, other receptors such as $\alpha_{v} \beta_{3}$ integrin, which mediates large vessel endothelial cell adhesion to fibrinogen, may mediate endothelial cell adhesion to the fibrin gel matrix. In support of this concept, we have previously shown that the coordinate interaction of CSPG and $\alpha_{4} \beta_{1}$ integrin facilitates cell adhesion to fibronectin (45). These data suggest that the coordinate interaction of matrix receptors may be important in mediating such cellular behavior as adhesion and migration.

The action of xylosides on protein synthesis is complex. $\beta-\mathrm{D}$ xyloside is a specific inhibitor of xylose-linked proteoglycan assembly and inhibits the synthesis of xylose-linked proteoglycans such as CSPG (26). $\alpha$-D xyloside, the control enantiomer of $\beta$-D xyloside used in this study, does not inhibit xylose linked proteoglycan assembly. However, both xylosides have been shown to inhibit total protein synthesis and specifically decrease fibronectin synthesis in large vessel endothelial cells (46). This leaves open the possibility that the effect of $\beta$-D xyloside on endothelial cell invasion may not only be due to interruption of CSPG function, but also due to modulation of fibronectin synthesis. However, in support of the role of CD44-related CSPG in mediating endothelial cell migration and invasion are the inhibition assays using chondroitinase $\mathrm{ABC}$ and anti-CD44 antibodies. The migration of endothelial cells on fibrinogen were significantly decreased using these reagents indicating that the CD44-related CSPG molecule itself is important in mediating locomotion. In further support of the role of CSPG in mediating invasion is the finding that $\alpha$-D xyloside does not significantly block cell invasion. $\alpha$-D xyloside inhibits both total protein and fibronectin synthesis but does not affect CSPG synthesis. This implies that the inhibition of CSPG synthesis by $\beta$-D xyloside is largely responsible for the inhibition of invasion. Furthermore, to ensure that disruption of endothelial cell interaction with fibrin and not other matrix components contaminating the fibrin matrix was the mechanism by which $\beta$-D xyloside inhibited invasion, HPLC-DEAE purified fibrinogen was used to make the fibrin gels. Additionally, invasion assays were performed using hylauronidase treated gels. Despite these treatments, endothelial cell invasion was inhibited indicating that disruption of CSPG interaction with fibrin and not other ECM proteins was the likely mechanism of inhibition of invasion by $\beta$-D xyloside. Further investigations aimed at examining whether CD44 core protein and/or chondroitin sulfate bind fibrinogen and studies which define whether specific domains on the fibrinogen molecule mediate receptor interaction are needed to fully understand the role of this cell surface matrix receptor in mediating microvascular endothelial cell migration and invasion.

\section{Acknowledgments}

The authors wish to thank Peter Bitterman and Mark Peterson for their excellent technical advice and critical review of the manuscript.
This research has been supported by grant F32 HL-08051-02 (Dr. Henke), and NHLBI SCOR in Acute Lung Injury HL 50152-01 (Project 2; Dr. Henke) from the National Institutes of Health. Additional support includes NIH grant CA 43924 (Dr. McCarthy), American Cancer Society grant CB-101 (Dr. McCarthy), and Leukemia Task Force (Dr. McCarthy).

\section{References}

1. Brown, L.F., A.M. Dvorak, and H.F. Dvorak. 1989. Leaky vessels, fibrin deposition, and fibrosis: a sequence of events common to solid tumors and to many other types of disease. Am. Rev. Respir. Dis. 140:1104-1107.

2. Henke, C., V. Fiegel, M. Peterson, M. Wick, D. Knighton, J. McCarthy, and P.Bitterman. 1991. Identification and partial characterization of angiogenesis bioactivity in the lower respiratory tract after acute lung injury. J. Clin. Invest. $88: 1386-1395$.

3. Henke, C., W. Marinelli, J. Jessurun, J. Fox, D. Harms, M. Peterson, L. Chiang, and P. Doran. 1993. Macrophage production of basic fibroblast growth factor in the fibroproliferative disorder of alveolar fibrosis after lung injury. Am. J. Pathol. 143:1189-1199.

4. Dvorak, H.F., V.S. Harvey, P. Estrella, L.F. Brown, J. McDonagh, and A.M. Dvorak. 1987. Fibrin containing gels induce angiogenesis. Implications of tumor stroma generation and wound healing. Lab. Invest. 57:673-686.

5. Brown, L.F., N. Lanir, J. McDonagh, K. Tognazzi, A.M. Dvorak, and H.F. Dvorak. 1993. Fibroblast migration in fibrin gel matrices. Am. J. Pathol. 142:273-283.

6. Cheresh, D.A. 1987. Human endothelial cells synthesize and express an Arg-Gly-Asp-directed adhesion receptor involved in attachment of fibrinogen and von Willebrand factor. Proc. Natl. Acad. Sci. USA. 84:6471-6475.

7. Charo, I.F., L.S. Bekeart, and D.R. Phillips. 1987. Platelet glycoprotein IIb-IIIa-like proteins mediate endothelial cell attachment to adhesive proteins and the extracellular matrix. J. Biol. Chem. 262:9935-9938.

8. Dejana, E., L.R. Languino, S. Colella, G.C. Corbascio, E. Plow, M. Ginsberg, and P.C. Marchisio. 1988. The localization of a platelet GpIIb-IIIa-related protein in endothelial cell adhesion structures. Blood. 71:566-572.

9. Cheresh, D.A., S.A. Berliner, V. Vicente, and Z.M. Ruggeri. 1989. Recognition of distinct adhesive sites on fibrinogen by related integrins on platelets and endothelial cells. Cell. 58:945-953.

10. Augustin-Voss, H.G., and B.U. Pauli. 1992. Migrating endothelial cells are distinctly hyperglycosylated and express specific migration-associated cell surface glycoproteins. J. Cell Biol. 119:483-491.

11. Kinsella, M.G., and T.N. Wight. 1986. Modulation of sulfated proteoglycan synthesis by bovine aortic endothelial cells during migration. J. Cell Biol. 102:679-687.

12. Garrigues, H.J., M.W. Lark, S. Lara, I. Hellstrom, K.E. Hellstrom, and T.N. Wight. 1986. The melanoma proteoglycan: restricted expression on microspikes, a specific microdomain of the cell surface. J. Cell Biol. 103:16991710 .

13. Faassen, A.E., J.A. Schrager, D.J. Klein, T.R. Oegema, J.R. Couchman, and J.B. McCarthy. 1992. A cell surface chondroitin sulfate proteoglycan, immunologically related to CD44, is involved in type I collagen-mediated melanoma cell motility and invasion. J. Cell Biol. 116:521-531.

14. Kalomiris, E.L., and L.Y.W. Bourguignon. 1988. Mouse T lymphoma cells contain a transmembrane glycoprotein (gp85) that binds ankyrin. J. Cell Biol. 106:316-327.

15. Lokeshwar, V.B., and L.Y.W. Bourguignon. 1992. The lymphoma transmembrane glycoprotein gp85 (CD44) is a novel guanine nucleotide-binding protein which regulates gp85 (CD44)-ankyrin interaction. J. Biol. Chem. 267: 22073-22078.

16. Jacobson, K., D. O'dell, B. Holifield, T.L. Murphy, and J.T. August. 1984. Redistribution of a major cell surface glycoprotein during cell movement. J. Cell Biol. 99:1613-1623.

17. Underhill, C. 1992. CD44: the hyaluronan receptor. J. Cell. Sci. 103:293298

18. Peach, R.J., D. Hollenbaugh, I. Stamenkovic, and A. Aruffo. 1993. Identification of hyaluronic acid binding sites in the extracellular domain of CD44. J. Cell Biol. 122:257-264.

19. Jalkanen, S., M. Jalkanen, R. Bargatze, M. Tammi, and E.C. Butcher 1988. Biochemical properties of glycoproteins involved in lymphocyte recognition of high endothelial venules in man. J. Immunol. 141:1615-1623.

20. Stamenkovic, I., M. Amiot, J.M. Pesando, and B. Seed. 1989. A lymphocyte molecule implicated in lymph node homing is a member of the cartilage link protein family. Cell. 56:1057-1062.

21. Goldstein, L.A., D.F.H. Zhou, L.J. Picker, C.N. Minty, R.F. Bargatze, J.F. Ding, and E.C. Butcher. 1990. A human lymphocyte homing receptor, the Hermes antigen, is related to cartilage proteoglycan core and link proteins. Cell. 56:1063-1072.

22. Thomas, L., R. Byers, J. Vink, and I. Stamenkovic. 1992. CD44H regulates tumor cell migration on hyaluronate-coated substrate. J. Cell Biol. 118: 971-977. 
23. Gunthert, U., M. Hofmann, W. Rudy, S. Reber, M. Zoller, I. Baußmann, S. Matzku, A. Wenzel, H. Ponta, and P. Herrlich. 1991. A new variant of glycoprotein CD44 confers metastatic potential to rat carcinoma cells. Cell. 65 : $13-24$

24. Rudy, W., M. Hofmann, R. Schwartz-Albiez, M. Zoller, K.H. Heider, H. Ponta, and P. Herrlich. 1993. The two major CD44 proteins expressed on a metastatic rat tumor cell line are derived from different splice variants: each one individually suffices to confer metastatic behavior. Cancer Res. 53:1262-1268.

25. Sy, M.S., Y.J. Guo, and I. Stamenkovic. 1991. Distinct effects of two CD44 isoforms on tumor growth in vivo. J. Exp. Med. 174:859-866.

26. Schwartz, N.B. 1977. Regulation of chondroitin sulfate synthesis. J. Biol. Chem. 252:6316-6321.

27. McCarthy, J.B., S.T. Hagen, and L.T. Furcht. 1986. Human fibronectin contains distinct adhesion-and motility-promoting domains for metastatic melanoma cells. J. Cell Biol. 102:179-188.

28. Laemmli, U.K. 1970. Cleavage of structural proteins during the assembly of the head of bacteriophage $\mathrm{T}_{4}$. Nature (Lond.). 227:680-685.

29. Bennett, K.L. D.G. Jackson, J.C Simon, E Tanczos, R Peach, B. Modrell, I. Stamenkovic, G. Plowman, and A. Aruffo. 1995. CD44 isoforms containing exon $\mathrm{V} 3$ are responsible for the presentation of heparin-binding growth factor. J. Cell Biol. 128:687-698.

30. van Weering, D.H.J., P.D. Baas, and J.L. Bos. 1993. A PCR-based method for the analysis of human CD44 splice products. PCR Methods Appl. 3: 100-106.

31. Screaton, G.R., M.V. Bell, D.G. Jackson, F.B. Cornelis, U. Gerth, and J.I. Bell. 1992. Genomic structure of DNA encoding the lymphocyte homing receptor CD44 reveals at least 12 alternately splice exons. Proc. Natl. Acad. Sci. USA. 89:12169-12164.

32. Yeo, T-K., L. Brown, and H.F. Dvorak. 1991. Alterations in proteoglycan synthesis common to healing wounds and tumors. Am. J. Pathol. 138:14371450.

33. Gross, J.L., D. Moscatelli, and D. Rifkin. 1983. Increased capillary endothelial cell protease activity in response to angiogenic stimuli in vitro. Proc. Natl. Acad. Sci. USA. 80:2623-2727.

34. Moscatelli, D., M. Presta, and D. Rifkin. 1986. Purification of a factor from human placenta that stimulates capillary endothelial cell protease production, DNA synthesis and migration. Proc. Natl. Acad. Sci. USA. 83:2091-2095.

35. Banda, M.J., G.S. Herron, G. Murphy, Z. Werb, and K.S. Dwyer. 1988.
Proteinase induction by endothelial cells during wound repair. In Growth Factors and Other Aspects of Wound Healing: Biological and Clinical Implications: Proceedings of the Second International Symposium on Tissue Repair Held at the Innisbrook Resort, Tarpon Springs, Florida, May 13-17, 1987 Adrian Barbul, editor. Alan R. Liss, Inc., New York. 117-130.

36. Montesano, R., M.S. Pepper, U. Mohle-Steinlein, W. Risau, E.F. Wagner, and L. Orci. 1990. Increased proteolytic activity is responsible for the aberrant morphogenetic behavior of endothelial cells expressing the middle T oncogene. Cell. 62:435-445.

37. Howard, P.S., J.C. Myers, S.F. Gorfein, and E.J. Macarak. 1991. Progressive modulation of endothelial cell phenotype during in vitro blood vessel formation. Dev. Biol. 146:325-338.

38. Montesano, R., and L. Orci. 1987. Phorbol esters induce angiogenesis in vitro from large vessel endothelial cells. J. Cell. Physiol. 130:284-291.

39. Aruffo, A., I. Stamenkovic, M. Melnick, C.B. Underhill, and B. Seed. 1990. CD44 is the principal cell surface receptor for hyaluronate. Cell. 61:13031313.

40. Jalkanen, S., and M. Jalkanen. 1992. Lymphocyte CD44 Binds the COOH-terminal heparin-binding domain of fibronectin. J. Cell Biol. 116:817825

41. Wayner, E.A., and W.G. Carter. 1987. Identification of multiple cell adhesion receptors for collagen and fibronectin in human fibrosarcoma cells possessing unique $\alpha$ and common $\beta$ subunits. J. Cell Biol. 105:1873-1884.

42. St. John, T., J. Meyer, R. Idzerda, and W.M. Gallatin. 1990. Expression of CD44 confers a new adhesive phenotype on transfected cells. Cell. 60:45-52.

43. Tarone, G., R. Ferracini, G. Galetto, and P. Comoglio. 1984. A cell surface integral membrane glycoprotein of $85,000 \mathrm{~mol} \mathrm{wt}$ (gp85) associated with Triton X-100-insoluble cell skeleton. J. Cell Biol. 99:512-519.

44. Lacy, B.E., and C.B. Underhill. 1987. The hyaluronate receptor is associated with actin filaments. J. Cell Biol. 105:1395-1404.

45. Iida, J., A.P.N. Skubitz, L.T. Furcht, E.A. Wayner, and J.B. McCarthy 1992. Coordinate role for cell surface chondroitin sulfate proteoglycan and $\alpha_{4} \beta_{1}$ integrin in mediating melanoma cell adhesion to fibronectin. J. Cell Biol. 118: 431-444.

46. Canfield, A.E., A.B. Sutton, D.R. Hiscock, J.T. Gallagher, and A.M. Schor. 1994. Alpha- and beta-xylosides modulate the synthesis of fibronectin and thrombospondin-1 by endothelial cells. Biochem. Biophys. Acta. 1200:249258 . 